\title{
Habeas CORPuS AND COVID-19: In THE MIDST OF a Viral Pandemic, Can the “Great Writ" Provide Home Supervision to At-Risk Plaintiff InMATes?
}

\author{
JAKE ZURSCHMIEDE*
}

\section{INTRODUCTION}

The World Health Organization declared the novel SARS-CoV-2 coronavirus (hereinafter "COVID-19," "COVID," or "pandemic") a global pandemic in March 2020. 'Within the span of one summer, all of the top ten clusters of COVID-19 in the United States were linked to prisons and jails. ${ }^{2}$ By October 2020, there were nearly 1,000 COVID-related deaths of inmates in prisons and jails, more than the total COVID-related deaths from nineteen different states and Washington D.C. put together. ${ }^{3}$ Four months later, this total more than doubled to at least 2,400 COVID-related deaths among the total American incarcerated population. ${ }^{4}$ Ultimately, by mid-December 2020 , one in every five state and federal prisoners had tested positive for COVID-19, a rate over four times that of the general population. ${ }^{5}$ Overall, the national COVID mortality rate among prisoners has remained approximately $45 \%$ higher than the overall rate. ${ }^{6}$

In March 2020, the Center for Disease Control and Prevention ("CDC") established that spread of the novel coronavirus is transmitted mainly from person-to-person within close, six-foot contact with one another. ${ }^{7}$ The CDC also advised the spread of the disease occurs via respiratory droplets produced when an infected person coughs or sneezes. According to the CDC, "the droplets can land in the mouths or noses of people who are nearby or possibly be inhaled into the lungs."

While the spiking rates among the incarcerated population are significant, the

* J.D. Candidate, 2022, Indiana University Robert H. McKinney School of Law; B.A., 2019, Hanover College.

1. Emily Widra, Visualizing Changes in the Incarcerated Population During COVID-19, PRISON POL'Y INITIATIVE (Sept. 10, 2020), https://www.prisonpolicy.org/blog/2020/09/10/ pandemic_population_changes/ [https://perma.cc/MM9X-HFFW].

2. Id.

3. $I d$.

4. A State-by-State Look at Coronavirus in Prisons, Marshall Project, https://www. themarshallproject.org/2020/05/01/a-state-by-state-look-at-coronavirus-in-prisons [https://perma.cc/QMX7-CRB8] (last visited Feb. 17, 2021).

5. Beth Schwartzapfel et al., 1 in 5 Prisoners in the U.S. Has Had COVID-19, MARshall ProjeCt (Dec. 18, 2020, 6:00 AM), https:/www.themarshallproject.org/2020/12/18/1-in-5prisoners-in-the-u-s-has-had-covid-19 [https://perma.cc/5J8Q-7TMZ].

6. Id.

7. How COVID-19 Spreads, Ctr. Disease Control \& Prevention, https://www.cdc.gov/ coronavirus/2019-ncov/transmission/index.html [https://perma.cc/ELL2-9MM3] (last visited Feb. 17, 2021).

8. $I d$. 
underlying statistics of viral transmissibility in federal prisons are staggering. ${ }^{9}$ The federal prison system currently houses over 140,000 inmates. ${ }^{10}$ While these federal prisons may appear to be closed environments because prisoners cannot leave and return to the facility on their own volition, prison staff members have the ability to come and go as they please, providing opportunities for the disease to be introduced into a prison. ${ }^{11}$ Federal prisons typically hold hundreds of prisoners who live in close proximity to one another, and in some facilities, prisoners live in dormitory-style housing where many share the same space. ${ }^{12}$ Even if prisoners are housed in individual cells, they typically share the same ventilation system with prisoners in other cells. ${ }^{13}$

As of June 2021, 240 federal inmates and four Bureau of Prisons ("BOP”) staff members have died from COVID-19. ${ }^{14}$ Of the over 100,000 federal inmates who have been tested for COVID-19, over 47,000 - almost half - have been positive. ${ }^{15}$ The BOP has placed just over 27,000 inmates on home confinement, which includes prisoners who completed their sentence within that time frame. ${ }^{16}$ This comprises fewer than $20 \%$ of federally incarcerated individuals. ${ }^{17}$ According to Homer Venters, an epidemiologist and member of the Biden-Harris COVID-19 Health Equity Task Force, these statistics are "likely an undercount of infections in settings where crowding makes it easy for the virus to spread, and inadequate health care leaves populations especially vulnerable." ${ }^{18}$

In response to the viral spread of COVID-19 among prison populations, Congress passed the Coronavirus Aid, Relief, and Economic Security ("CARES") Act, which was executively signed into law on March 27, 2020. ${ }^{19}$ The CARES

9. See COVID-19 Coronavirus, Fed. BuREAu Prisons, https://www.bop.gov/coronavirus/\# $: \sim$ text=COVID\%2D19\%20Cases\&text=Currently $\% 2 \mathrm{C} \% 2044 \% 2 \mathrm{C} 644 \% 20$ inmates $\% 20$ and $\% 20$ 4\%2C502,occurred $\% 20$ while $\% 20$ on $\% 20$ home $\% 20$ confinement [https://perma.cc/2UGR-EKDG] (last visited June 24, 2021).

10. Wendy Sawyer \& Peter Wagner, Mass Incarceration: The Whole Pie 2020, Prison POL'Y INITIATIVE (March 24, 2020), https://www.prisonpolicy.org/reports/pie2020.html [https:// perma.cc/8L6P-F8S3]. Over two million Americans were incarcerated nationwide per a March 2020 report by Prison Policy Initiative, comprising nearly 700 per every 10,000 U.S. residents. Id.

11. Maria Morris, Are Our Prisons and Jails Ready for COVID-19?, AM. CIV. LiBERTIES UNION (Mar. 6, 2020), https://www.aclu.org/news/prisoners-rights/are-our-prisons-and-jails-readyfor-covid-19/ [https://perma.cc/23QB-EDJ7].

12. See id.

13. Id.

14. COVID-19 Coronavirus, supra note 9.

15. Id.

16. $I d$.

17. $I d$.

18. Rachel Harrison, Fighting COVID Behind Bars, N.Y.U. (Mar. 23, 2021) http://www.nyu. edu/about/news-publications/news $/ 2021 / \mathrm{march} /$ covid-behind-bars-venters.html [https://perma.cc/W45B-L2C7] (emphasis added).

19. The CARES Act Works for All Americans, U.S. DEP'T TREASURY, https://home.treasury. gov/ policy-issues/cares [https://perma.cc/V3FX-UMHQ] (last visited Nov. 8, 2020). 
Act provided an economic stimulus to U.S. citizens and gave the U.S. Attorney General the authority to expand the cohort of inmates who could be considered for release to home confinement. ${ }^{20}$ Home confinement is defined as "any judicially or administratively imposed condition requiring a participant to remain in [their] residence for any portion of the day." ${ }^{21}$ Those in home confinement are often geographically monitored with the assistance of electronic equipment. ${ }^{22}$ The Attorney General can effectuate an expansion of this cohort upon a finding that "emergency conditions are materially affecting the functioning of the Bureau of Prisons." ${ }^{23}$ The vague nature of the home release of prisoners under the Act, however, makes it so that legal professionals, like defense attorneys and nonprofit advocates, such as the American Civil Liberties Union ("ACLU"), should make an inquiry into the availability of legal recourse for prisoners to obtain home release. This is especially pertinent to those prisoners with conditions that make them substantially at-risk if they catch the virus. Many of these inmates who have not been granted home release under the CARES Act have brought suit against their federal prisons, oftentimes petitioning the court to recognize the writ of habeas corpus. ${ }^{24}$ Habeas corpus is an ancient common law writ. ${ }^{25}$ The writ directs the entity that holds an individual in custody to produce that individual before the court. ${ }^{26}$ This mechanism is used by plaintiff inmates to correct alleged violations of personal liberty through judicial inquiry into the legality of their custody. ${ }^{27}$

This Note regards the potential of current prison inmates who are not covered by or are otherwise excluded from CARES Act protections to successfully raise a habeas corpus claim to appeal for home confinement on grounds of adverse confinement location or overall condition of an inmate's confinement. There exists a split between the Sixth Circuit and the Seventh Circuit regarding the ability of a court to grant the writ of habeas corpus pursuant to 28 U.S.C. $\S 2241$ on the grounds of conditions of an inmate's confinement. The Sixth Circuit has held that plaintiffs can petition for habeas on the grounds of adverse confinement

20. Id.; Memorandum from Att'y Gen. William P. Barr to Dir. Bureau Prisons (Apr. 3, 2020), https://www.bop.gov/coronavirus/docs/bop_memo_home_confinement_april3.pdf [https://perma.cc/3946-Z258].

21. See Jody Klein-Saffran, Electronically Monitored Home Confinement - Not a Panacea for Corrections, But a Useful Tool, InT'L Ass'N Residential \& CMTY. AlteRnAtives, May/June 1991, 30-1, https://www.bop.gov/resources/research_projects/published_reports/gen_program_ eval/oreprelectronicmon.pdf [https://perma.cc/M2ZC-78N4].

22. Id.

23. Memorandum from Att'y Gen. William P. Barr, supra note 20; see also The CARES Act Works for All Americans, supra note 19.

24. See, e.g., Savage v. Warden of FCI Pekin, No. 20-cv-1181, 2020 WL 4060768 (C.D. Ill. July 20, 2020).

25. Habeas Corpus, BRITANNICA, https://www.britannica.com/topic/habeas-corpus [https:// perma.cc/C6DP-FGGP] (last visited Feb. 12, 2021).

26. $I d$.

27. $I d$. 
conditions, whereas the Seventh Circuit precludes these plaintiffs from doing so. ${ }^{28}$ For example, in the recent U.S. District Court for the Central District of Illinois case Savage v. Warden of PCI Pekin, the Court precluded a plaintiff inmate from COVID-justified home confinement on the basis of habeas corpus. The court held that the writ did not apply because the plaintiff, who sought release by petitioning for a habeas writ on the basis of conditions of his confinement, did not challenge the fact or duration of his sentence. ${ }^{29}$

The aforementioned circuit split arises from the 1973 Supreme Court decision Preiser v. Rodriguez, where the Court found that a claim against the deprivation of good-time credits that might have led to an early release for the plaintiff inmate was cognizable under habeas corpus jurisdiction for challenging the fact or duration of the plaintiff's confinement. ${ }^{30}$ This holding left open the question as to what qualifies as a "condition of confinement." ${ }^{11}$ Historically, the Seventh Circuit has stuck with this standard - that habeas corpus can only be brought as to challenge the fact or duration of a sentence, which effectively barred the plaintiff's COVID-related claim in Savage. ${ }^{32}$ Conversely, the Sixth Circuit has held that habeas corpus jurisdiction is available in a specific circumstance - if the conditions of a sentence are so adverse as to effectively challenge the legality of the confinement. ${ }^{33}$ In other words, the Sixth Circuit has recognized that habeas jurisdiction is able to cover claims involving conditions of confinement that rise to an extremely adverse level. ${ }^{34}$

As such, the guiding question of this Note centers on the willingness of courts to deem viral pandemic-related dangers as so materially deleterious to inmate health as to comprise the very legality of an inmate's confinement. While the theory of the Sixth Circuit's ruling is that a court that finds a plaintiff inmate to be under such danger is more likely to admit a petition for the writ of habeas corpus, courts have laterally held during the COVID-19 pandemic that a plaintiff inmate cannot effectuate a conditions of confinement claim with a petition for the writ of habeas corpus on the basis of pandemic-related dangers. ${ }^{35}$ This is not to say that hope for plaintiff inmates seeking a habeas writ on the basis of adverse conditions of confinement during the pandemic is completely lost; some jurisdictions do recognize habeas admissibility in conditions of confinement claims and, as such, hold case law that proves more analogous to COVID-era claims than courts have recognized. Ultimately, the nation continues to deal with a multifaceted viral threat that has lasted more than a calendar year. On its face, an established doctrine like habeas corpus should not only provide a supplemental

28. See Preiser v. Rodriguez, 411 U.S. 475 (1973) (emphasis added).

29. See Warden of FCI Pekin, 2020 WL 4060768.

30. Rodriguez, 411 U.S. at 475.

31. See id.

32. Warden of FCI Pekin, $2020 \mathrm{WL} 4060768$, at *2.

33. Id. at $* 3$.

34. See id.

35. See, e.g., id. See also Miller v. Beard, No. 21-11, 2021 U.S. Dist. LEXIS 14246, at *4

(E.D. Ky. Jan. 26, 2021) (emphasis added). 
option for plaintiff inmates seeking recourse when no other avenue is available, but its admittance in prison health-based claims would provide precedent for any future threat to communal health.

The circuit split reveals the theoretical nature behind the potential for habeas corpus to work in providing relief to those federal prisoners not selected for home confinement. Before detailing the split, however, this Note outlines several factors vital to contextualizing jurisdictional precedent - (a) the definition of habeas corpus; (b) the intersection of COVID-19 and the Eighth Amendment "conditions of confinement" prong; (c) the deficiencies of the former Attorney General's direction to federal prisons; and (d) the inadequacy of compassionate release to cover all aggrieved plaintiff inmates.

\section{BACKGROUND INFORMATION}

\section{A. The Writ of Habeas Corpus}

Under the authority of 28 U.S.C. $\S 2241$, habeas corpus, otherwise known as the "Great Writ," is the legal procedure that keeps the government from holding individuals in detention indefinitely without showing cause. ${ }^{36}$ Per $\S 2241$ (a), writs of habeas corpus may be "granted by the Supreme Court, any justice thereof, the district courts and any circuit judge within their respective jurisdictions." ${ }^{\prime 37}$ Relevant to this Note, plaintiff inmates not only petition for the court to grant the writ for the purpose of "judicial review" of their sentence, but often attempt to pair the writ with a conditions of confinement claim under the Eighth Amendment. ${ }^{38}$

\section{B. The Eighth Amendment - Conditions of Confinement}

Despite the Eighth Amendment imposing a duty on correctional facilities to provide inmates with health care, the American prison system is generally not administered in a method conducive to providing sufficient or affordable care for at-risk inmates, especially during a viral pandemic. ${ }^{39}$ As this Note principally

36. FAQs: What is Habeas Corpus, CENT. CONSt. RTs., https://ccrjustice.org/home/getinvolved/tools-resources/fact-sheets-and-faqs/faqs-what-habeas-corpus [https://perma.cc/4BQ5V4R5] (last updated Jan. 11, 2010).

37. 28 U.S.C. $\S 2241$.

38. Habeas Corpus, Black's Law Dictionary (11th ed. 2019) Habeas corpus . . . [Law Latin "that you have the body"] (18c) A writ employed to bring a person before a court, most frequently to ensure that the person's imprisonment or detention is not illegal (habeas corpus ad subjiciendum). In addition to being used to test the legality of an arrest or commitment, the writ may be used to obtain judicial review of (1) the regularity of the extradition process, (2) the right to or amount of bail, or (3) the jurisdiction of a court that has imposed a criminal sentence.

39. Jill Burke, While America Shelters at Home, Confinement Endangers the Incarcerated, Univ. S. Cal. Annenberg Media (Sept. 11, 2020, 9:25 AM), http://www.uscannenbergmedia. com/2020/09/11/while-america-shelters-at-home-confinement-endangers-the-incarcerated/ [https://perma.cc/6Y4C-QTU4]. 
concerns a legal theory of recourse for inmates being put at a high risk of contracting the virus due to their communal living arrangements, the Eighth Amendment analysis of this Note addresses only its "conditions of confinement" clause. The Amendment stipulates that "[e]xcessive bail shall not be required, nor excessive fines imposed, nor cruel and unusual punishments inflicted." 40

Per Supreme Court case Rhodes v. Chapman, "it is unquestioned that '[c]onfinement in a prison [...] is a form of punishment subject to scrutiny under the Eighth Amendment standards." "41 The Court further stated that conditions of confinement "must not involve the wanton and unnecessary infliction of pain, nor may they be grossly disproportionate to the severity of the crime warranting imprisonment." ${ }^{42}$ The Supreme Court in Wilson v. Seiter established that parties who bring conditions of confinement claims must meet both a subjective and objective standard. ${ }^{43}$ According to the Court, before conditions of confinement can qualify as "punishment," claimants must prove a culpable, "wanton" state of mind on the part of prison officials. ${ }^{44}$ In the context of general prison conditions, a context relevant to a COVID-based inquiry on the preparedness and ability of detention centers to properly handle the dangers of the virus, this culpable state of mind is "deliberate indifference." ${ }^{45}$ In Farmer v. Brennan, the Supreme Court furthered the definition of "deliberate indifference" as it pertains to Eighth Amendment conditions of confinement claims. ${ }^{46}$ The Court established that the standard of "deliberate indifference" goes beyond disregarding an "unjustifiably high risk of harm that is either known or so obvious that it should be known." Instead, "it requires a finding of recklessness only when a person disregards a risk of harm of which he is aware." $" 48$

Further complicating matters for inmates seeking merely adequate conditions of confinement, the legal bar for claims against prison administration for deliberate indifference to serious inmate needs was set high by the Supreme Court in Estelle v. Gamble. ${ }^{49}$ There, the Court held that (a) deliberate indifference constitutes the "unnecessary and wanton infliction of pain" barred by the Eighth Amendment; but (b) the action at bar must exceed an "inadvertent failure to

40. U.S. Const. amend. VIII, $\S 2$.

41. Rhodes v. Chapman, 452 U.S. 337, 345 (1981) (quoting Hutto v. Finney, 437 U.S. 678, 685 (1978)).

42. Id. at 347.

43. See Wilson v. Seiter, 501 U.S. 294 (1991). The subjective prong details that plaintiffs are burdened with proving prison officials failed to create safe conditions for prisoners during the COVID-19 pandemic, while the objective prong details the inquiry as to whether deprivation was sufficiently serious for plaintiffs to prevail. Id.

44. Id. at 297.

45. Id. at 303 .

46. See Farmer v. Brennan, 511 U.S. 825 (1994).

47. Id. at 836 .

48. Id. at 837 .

49. See Estelle v. Gamble, 429 U.S. 97 (1976). 
provide adequate [care]" in order to be found unconstitutional. ${ }^{50}$

The jurisprudential history of prison conditions of confinement has generally not favored the most physically or financially-vulnerable prisoners, and this precedent does not bode well for a new class of plaintiff inmates seeking recourse in COVID-19-related claims. ${ }^{51}$ For instance, incarcerated individuals are over five times more likely to test positive for COVID-19 than the rest of the U.S. population. ${ }^{52}$ Inside prisons, administration has struggled to mitigate the dangers that the virus has brought to the communal health of inmates. ${ }^{53}$ Janet Lee Walton, president of the Coalition for Prison Reform, advised inmates in a low-security portion of the Federal Correctional Institution of Yazoo City, Mississippi, to sleep head-to-toe in an attempt to expand their breathing space. ${ }^{54}$ This was likely the best the inmates could do to mitigate the dangers of viral transmission in their living space, where three inmates shared a cell "no bigger than the average bathroom." In one particular institution in Virginia, the Lawrenceville Correctional Center, there is no doctor on-site for large portions of the day, and, as of September 2020, there were no nurses on-site due to understaffing at the institution. ${ }^{56}$ According to Jill Burke of USC Annenberg Media, these accounts "go[] to show that a lack of appropriate [. . .] care for incarcerated people is not a new phenomenon. Rather, the COVID-19 pandemic is merely exacerbating and exposing a pre-existing problem." ${ }^{57}$ Task Force member Homer Venters, too, recognizes the poor conditions of confinement shared amongst prison inmates during the pandemic in explaining that " $[. .$.$] the physical confines of detention$ settings promote the spread of COVID-19." ${ }^{58}$ As an exacerbating element of viral transmissibility in these prisons, Venters highlights "the manner in which we have filled carceral settings with high-risk people, those with physical and behavioral problems, and people who are older." 59

Similarly, the negative impact of the viral pandemic on prison operations has caused judicial protocol to be compromised ${ }^{60}$ Due to a state ordinance, New York defense attorneys could not visit their imprisoned clients from mid-March to mid-July, and with the indefinite future of the virus, there is no guarantee that such inhibitions on in-person contact will not reappear. ${ }^{61}$ While recognizing the

50. Id. at 105-106.

51. See Burke, supra note 39.

52. Id.

53. See id.

54. Id.

55. Id.

56. Id.

57. $I d$.

58. Harrison, supra note 18.

59. Id.

60. See Burke, supra note 39.

61. Id. (explaining that many requirements for constitutionality in New York were compromised during its judicial system shutdown in the summer of 2020, as the guarantee of a person being arrested on a felony to appear before a judge in a preliminary hearing within 128 
difficulty of such a process to continue when workplace congregation poses a threat to communal health in the midst of a viral pandemic, this also means that someone who was arrested on a high-level felony in mid-March would have sat in jail until mid-July without a preliminary hearing, which is a violation of a basic constitutional right. ${ }^{62}$ In the chance that a preliminary hearing would result in a favorable finding for the accused, a four-month incarceration is at stake, at which time the individual would be exposed to a close and communal living space during a viral threat deleterious to their own health. While the pandemic has matured over the course of a year, society is still at the precipice of how to properly deal with its dangers. As it pertains to the American prison system and the fragility of current prison preparedness to deal with the ramifications of a quickly moving virus, legal professionals should seek alternative means and theories in advocating for inmates, including release and home confinement. Venters identifies release as the most imperative means by which to mitigate the spread of the virus in prison settings. ${ }^{63}$ Venters' concept of release involves "working to identify high-risk people who are close to release dates or otherwise can be released without public safety concerns." ${ }^{64}$ Such a system, according to Venters, "decreases [inmates'] risk of contracting and dying from COVID-19, as well as increasing the ability of facilities to manage outbreaks. ${ }^{965}$

\section{The Barr Memos}

In late March 2020, former U.S. Attorney General William Barr issued memoranda and other communications directing the BOP in its handling of inmate relocation per the CARES Act. ${ }^{66}$ These communications established an overall plan, but for the forthcoming reasons may have lacked the specificity required to insulate that plan from under-inclusiveness (which is to say that fewer inmates were covered by the plan than was intended) and disparate impact concerns. In his March 26, 2020 memo, the former Attorney General outlined a non-exhaustive list of discretionary factors to the BOP Director to be used by federal facilities in determining which inmates should be granted home confinement. ${ }^{67}$ This list includes inmate age, vulnerability, conduct in prison, propensity for recidivism, and the nature of the inmate's conviction. ${ }^{68}$ Barr also

hours of the arrest was "thrown out the window").

62. Id.

63. Harrison, supra note 18.

64. Id.

65. Id.

66. See Memorandum from Att'y Gen. William P. Barr to Dr. Bureau Prisons (Mar. 26, 2020), https://www.bop.gov/coronavirus/docs/bop_memo_home_confinement.pdf [https://perma.cc/UGJ9-XM74].

67. Id.

68. Id. Barr listed the following relevant factors:

(a) "The age and vulnerability of the inmate to COVID-19, in accordance with the Centers for Disease Control (CDC) guidelines; 
detailed in his March 26 memo that inmates transferred to home confinement under this process would also be subject to location monitoring technology while in home detention. ${ }^{69}$ By confining prisoners to their homes or community supervision facilities, this location monitoring requirement works to curb the legitimate threat of over-inclusivity of home release (which is to say that more inmates were covered by the plan than was intended); that releasing prisoners en masse would create a less safe public sphere. ${ }^{70}$

In his April 3, 2020 memorandum to the BOP Director, Barr explained that the CARES Act vested his office with the authority to expand the cohort of inmates who can be considered for home release, albeit predicated on his finding that emergency conditions are "materially affecting the functioning of the Bureau of Prisons." give priority in granting home confinement to "the most vulnerable inmates at the most affected facilities." ${ }^{.72}$ Barr detailed that inmates are to be chosen by a less restrictive standard than outlined by the CARES Act in those facilities which pose a material threat to BOP operations. ${ }^{73} \mathrm{He}$ further stated that the extent by which an inmate's medical inhibitions are to be evaluated should be consistent with $\mathrm{CDC}$ regulations, and that any prisoner granted release is subject to a fourteenday quarantine at an appropriate BOP facility or, when deemed appropriate on a case-by-case basis, in the residence of the inmate. ${ }^{74}$ In doing so, the Office of the Attorney General ("OAG") put a majority of the weight of authority in deciding qualification for release in the hands of the BOP. ${ }^{75}$ Barr delegated to the BOP the

(b) The security level of the facility currently holding the inmate, with priority given to inmates residing in low and minimum security facilities;

(c) The inmate's conduct in prison, with inmates who have engaged in violent or gang-related activity in prison or who have incurred a BOP violation within the last year not receiving priority treatment under this Memorandum;

(d) The inmate's score under PATTERN, with inmates who have anything above a minimum score not receiving priority treatment under this Memorandum;

(e) Whether the inmate has a demonstrated and verifiable re-entry plan that will prevent recidivism and maximize public safety, including verification that the conditions under which the inmate would be confined upon release would present a lower risk of contracting COVID-19 than the inmate would face in his or her BOP facility;

(f) The inmate's crime of conviction, and assessment of the danger posed by the inmate to the community. Some offenses, such as sex offenses, will render an inmate ineligible for home detention. Other serious offenses should weigh more heavily against consideration for home detention."

69. Id.

70. Id. (emphasis added).

71. Memorandum from Att'y Gen. William P. Barr, supra note 20.

72. Id.

73. Id.

74. Id.

75. Id. 
task of providing supervision to its facilities in a manner consistent with the Attorney General's guidance, stating too that federal institutions will exert different levels of operative action based on (a) the quality and amount of their resources; and (b) the ability of their staff. ${ }^{76}$ Here, even Barr lamented that there is facially no way to guarantee that every federal institution will follow a uniform protocol in deciding which inmates qualify under, albeit, a more inclusive OAG standard of review. ${ }^{77}$ Ironically, such lack of uniformity allows for an underinclusiveness that leaves otherwise-eligible inmates without recourse in being granted home confinement based on individual risk factors. The federal prison system has reason, too, to limit the inclusivity of eligible prisoners. ${ }^{78}$ In his memorandum, Barr warned against releasing prison populations "en masse onto the streets," as doing so, according to Barr, "would pose profound risks to the public from released prisoners engaging in additional criminal activity, potentially including violence or heinous sex offenses." ${ }^{\prime 79}$ Barr characterized the decision-making vested in the BOP as needing to be of the "careful, individualized determinations BOP makes in the typical case" in order to curb the chance that prisoners that are more prone to recidivism would not be granted release. ${ }^{80}$ The Attorney General's Office labeled the determination of who has to stay and who gets to be partially released among the inmate population as needing to be "careful" and "individualized." ${ }^{\prime 1}$ Here, even when considering the criteria for release, it follows that Barr has given vague guidance as to how the $\mathrm{BOP}$ is to make these determinations. ${ }^{82}$

Barr's direction to the BOP may impede Homer Venters' vision of sweeping equitable release ${ }^{83}$ As argued by Eli Hager of The Marshall Project, Barr's home confinement plan "may exclude many vulnerable prisoners from being released, and may also create racial disparities in who gets out of prison." ${ }^{\prime \prime 4}$ In Barr's fourth prong of the March 26 memorandum list of factors to determine which prisoners qualify for home confinement, he "instructs the prison system to prioritize for release only those inmates who receive" the lowest possible score on PATTERN (Prisoner Assessment Tool Targeting Estimated Risk and Needs). ${ }^{85}$ PATTERN is a computerized "risk assessment" algorithm that deems white-collar offenders

76. $I d$.

77. Id.

78. See id.

79. Id.

80. Id.

81. Id.

82. See id.

83. See Harrison, supra note 18 (explaining that Venters' concept of release involves "working to identify high-risk people who are close to release dates or otherwise can be released without public safety concerns").

84. Eli Hager, How Bill Barr's COVID-19 Prisoner Release Plan Could Favor White People, COLORLines (Apr. 2, 2020, 10:05 AM), https://www.colorlines.com/articles/how-bill-barrs-covid19-prisoner-release-plan-could-favor-white-people [https://perma.cc/KL32-SMZF].

85. Id. 
generally safe to be let out of prison. ${ }^{86}$ Conversely, those incarcerated on drug charges or with a series of prior arrests face a less favorable outcome from the PATTERN system.$^{87}$ On this standard alone, the Department of Justice ("DOJ") has determined that use of the PATTERN system has a disparately negative impact on the Black community. ${ }^{88}$ According to the DOJ, only $7 \%$ of black men in federal prisons would be granted home confinement through PATTERN, whereas $30 \%$ of white men in federal prisons would be granted home confinement. ${ }^{89}$ Further, the PATTERN algorithm had not been "fully tested or independently reviewed" prior to its use as a determining factor in the potential home release of federal inmates due to pandemic-related dangers. ${ }^{90}$ Hager reported that, while less algorithmic and more circumstantial factors - including age, health, good conduct, and length of sentence-are included in Barr's March 26 memo, "they would be overruled by a poor score on the PATTERN assessment."191 Seeing as though the DOJ found that the PATTERN test operationally favors white prisoners who seek home confinement, it follows that the inclusion of the algorithm in BOP's greater assessment of who qualifies for home release underrepresents Black, Indigenous, and People of Color ("BIPOC") federal prisoners. ${ }^{92}$

\section{Compassionate Release}

Thus far, inmates have principally relied on motions for compassionate release in order to prevail when requesting home confinement, but their results have been overwhelmingly unfruitful. ${ }^{93}$ In the first three months of the COVID19 pandemic, over 10,000 federal inmates applied for compassionate release. ${ }^{94}$ Only 156 of these requests, or fewer than $2 \%$, were approved. ${ }^{95}$ Just over 2,000 New Jersey inmates, all of whom had less than a year remaining on their sentence, were released in November 2020, but this class of prisoners had to wait eight months after the pandemic began. ${ }^{96}$

For the forthcoming reasons, many inmates who lack a specific combination of qualifications may be without luck in motions for compassionate release, as the bar to relief set by the relevant federal statute has remained high. In the recent

86. Id.

87. Id.

88. See The First Step Act of 2018: Risk and Needs Assessment System, U.S. DEP'T JuST. OfF. ATT'Y GEN. (July 19, 2019), https://nij.ojp.gov/sites/g/files/xyckuh171/files/media/document/thefirst-step-act-of-2018-risk-and-needs-assessment-system_1.pdf [https://perma.cc/2CBU-H6Q8].

89. Id.

90. Hager, supra note 84.

91. Id.

92. Id.

93. Schwartzapfel et al., supra note 5.

94. Id.

95. Id.

96. Id. 
U.S. District Court for the Eastern District of Michigan case, Samy v. United States, the plaintiff inmate was able to prevail on a motion for compassionate release by satisfying two elements - (a) an exhaustion of administrative remedies; and (b) the showing of extraordinary and compelling reasons for release. ${ }^{97}$ The court held that the plaintiff, an incarcerated medical doctor, satisfied the first statutory element in part because he had "petitioned the BOP for compassionate release at least six times, at every administrative level." ${ }^{98}$ Additionally, the court held that the plaintiff satisfied the second statutory element by explaining that continuing his incarceration under the current pandemic could be a "lethal decision" when factoring in the plaintiff's age of 72 years, heart condition, diabetes, and asthma. ${ }^{99}$ While the court furnished the plaintiff inmate with a favorable decision here, his case was undoubtedly helped by facts supporting both statutory elements that may not mirror or even resemble those of other inmates seeking compassionate release. While Samy met an exception to the "exhaustion of administrative remedies" prong, other inmates seeking recourse may not be able to show such a record of filings. ${ }^{100}$ This is especially true when considering that those seeking release due to pandemic-imposed dangers are likely doing so in as short of a period of time as allowable, so as to limit exposure to adverse conditions. $^{101}$ While the court in Samy did recognize the danger of viral transmission posed to those in a communal setting, the plaintiff's showing of three different underlying medical conditions helped the court reason with the his legal theory. ${ }^{102}$ Under this standard, a plaintiff inmate who shows anything less than a combination of underlying health conditions may have a more difficult time being granted compassionate release under the statute. This, again, brings about the necessity of an inquiry into alternate means by which at-risk inmates may be granted proper release in the midst of a viral pandemic.

\section{CIRCUIT SPLIT AND JURISDICTIONAL SUPPORT}

\section{A. Seventh Circuit "Fact or Duration" Standard - A Blockade to Habeas Relief Exists, but the Blockade is Not as Strong as We Think}

While the Seventh Circuit is rich with case law that establishes the jurisdictional precedent of allowing habeas petitions only under a challenge to the "fact or duration" of a sentence, it has yet to face a question or controversy where conditions of confinement are so adverse as to challenge the "fact or duration" of the sentence. ${ }^{103}$ For example, in Waletzki v. Keohane, the Seventh Circuit found

97. See Samy v. U.S., No. 16-20610-1, 2020 WL 1888842 (E.D. Mich. Apr. 16, 2020).

98. $I d$. at $* 6$.

99. Id. at $* 10$.

100. Id. at $* 6$.

101. See id.

102. $I d$. at $* 8$.

103. See Savage v. Warden of FCI Pekin, No. 20-cv-1181, 2020 WL 4060768 (C.D. Ill. July 20, 2020). 
that, while the plaintiff inmate's claim for habeas-based release was within the habeas corpus jurisdiction of the district court, the plaintiff's claim did not succeed on the merits. ${ }^{104}$ Rather, the court held it should not intervene in policing the exercise of the prison officials' discretion in awarding "good-time" credits based on performance. ${ }^{105}$ According to the court, if the decision at bar to deny the plaintiff inmate good-time credits had been on the basis of religion, race, or "some other constitutionally forbidden criterion," the Court would have intervened, but nothing of that sort was alleged. ${ }^{106}$

Similarly, in Robinson v. Sherrod, a district court within the Seventh Circuit held that the federal habeas corpus statute cannot be used to challenge conditions of one's confinement. ${ }^{107}$ On appeal, the circuit court affirmed the holding, finding that the plaintiff inmate could not bring a $\S 2241$ habeas petition, as none of the alleged failures on the part of prison staff had even an indirect effect on duration of punishment. ${ }^{108}$ In Glaus v. Anderson, a prisoner suffering from hepatitis $\mathrm{C}$ who stopped receiving treatment from the institution could not prevail on his habeas corpus claim. ${ }^{109}$ The court reasoned that Glaus's habeas petition would have been proper had release been "among the possible remedies for an Eighth Amendment deliberate indifference claim." "110 The Seventh Circuit's precedent on the matter dictated that claims for the conditions of confinement are not covered under habeas, so the court found Glaus's complaint to be only potentially cognizable under a civil rights or a Federal Tort Claim Act-based claim. ${ }^{111}$ Glaus nevertheless cited Preiser and the circuit split in arguing that there is a potential for the court to grant his petition for habeas corpus. ${ }^{112}$ On this matter, the court stated, "[w]hile the Supreme Court has left the door open a crack for habeas corpus claims challenging prison conditions, it has never found anything that qualified." 113

It is not as if plaintiff inmates have not asked the Seventh Circuit to adopt a more habeas-friendly approach to COVID-19-based claims. ${ }^{114}$ While merely a district court case, in Maday v. Fluke, a Wisconsin prisoner incarcerated in a South Dakota prison brought a petition for the writ of habeas corpus based on his claim that the institution had not enacted safety measures to prevent the spread of the virus. ${ }^{115}$ The prisoner further claimed that he had underlying health

104. Waletzki v. Keohane, 13 F.3d 1079, 1081 (7th Cir. 1994).

105. Id. at 1082 .

106. Id.

107. Robinson v. Sherrod, 631 F.3d 839, 840-41 (7th Cir. 2011).

108. Id. at 843 . The plaintiff brought the action on the grounds of the prison apparently failing to investigate his complaints of back pain, failing to schedule for him a diagnostic MRI, and failing to administer to him appropriate medication.

109. See Glaus v. Anderson, 408 F.3d 382 (7th Cir. 2005).

110. Id. at 387.

111. Id.

112. Id.

113. Id.

114. See Maday v. Fluke, No. 20-cv343, 2020 WL 2769486 (W.D. Wis. May 28, 2020).

115. See id. 
concerns that would make contracting the virus particularly deleterious to his health. ${ }^{116}$ In a motion for reconsideration, the prisoner asked the court to adopt the reasoning of courts outside the Seventh Circuit in their more favorable handling of habeas corpus as a means of relief in conditions of confinement cases..$^{17}$ Denying the prisoner's request for reconsideration, the district judge made clear that "an Eighth Amendment conditions of confinement claim cannot be raised in a habeas petition, because release is not an available remedy to an Eighth Amendment claim." ${ }^{\prime 18}$ Further, the judge reiterated that the Seventh Circuit had not made an exception to its preclusion of habeas petitions for challenges to the condition of confinement. ${ }^{119}$

The question here becomes whether the danger of COVID-19 viral transmissibility in prisons qualifies as a condition of confinement adverse enough to challenge the "fact or duration" of an inmate's sentence. Referencing Glaus v. Anderson, despite the Supreme Court not finding a circumstance or pattern of facts justifying the establishment of an affirmative stance on the ability of habeas corpus to be used in a claim of adverse conditions of confinement, it has nevertheless "left the door open a crack." 120 Despite unfavorable findings for the plaintiff inmates in Savage and Maday, this "crack" could be wide enough for COVID-19 to fit in. In theory, the COVID-19 viral pandemic is such a categorically different threat than anything the American prison system has seen. The threat is exacerbated by the viral transmissibility at play, which hits hardest to those in close quarters, like in a prison. ${ }^{121}$ Considering Waletzki v. Keohane, too, the threat of potentially deadly viral transmission must rise above a claim for release based on the revocation of good-time credits, as the former pertains to potentially dire life-or-death circumstances. Naturally, an adverse finding would more significantly affect the constitutional rights of the aggrieved inmate housed in a COVID "hotspot" than it would affect a prisoner denied of good-time credits. ${ }^{122}$ The same can be said, too, when considering the plaintiff inmate's back pain in Robinson v. Sherrod. ${ }^{123}$ In a word, the mere life-or-death ramifications of relegating an individual to habitation in an environment adverse to public health must squeeze through the "crack" left by the Supreme Court in Preiser. It follows that this could at least raise the possibility that habeas can work to provide recourse for plaintiff inmates in a COVID context. The Sixth Circuit, in fact, has taken the more habeas-friendly approach to the split, and has historically allowed habeas to fit into the jurisprudential scheme. ${ }^{124}$ As a result, COVID-era cases that

116. Id. at $* 1$.

117. Id.

118. Id.

119. Id.

120. Glaus v. Anderson, 408 F.3d 382, 387 (7th Cir. 2005).

121. Burke, supra note 39.

122. Waletzki v. Keohane, 13 F.3d 1079, 1081 (7th Cir. 1994).

123. See Robinson v. Sherrod, 631 F.3d 839, 840-41 (7th Cir. 2011).

124. See, e.g., Savage v. Warden of FCI Pekin, No. 20-cv-1181, 2020 WL 4060768 (C.D. Ill. July 20, 2020). 
have arisen out of the Sixth Circuit should provide a model for other jurisdictions that have retained a strict construction of habeas corpus.

\section{B. Sixth Circuit "Legality” Standard - The Theory of Why Habeas Should Work in the Sixth Circuit}

Unlike the cases arising from the Seventh Circuit, the following cases form the basis of the habeas-friendly Sixth Circuit as it pertains to the Savage decision, which theoretically would provide recourse for plaintiff inmates challenging the very legality of their sentence under materially adverse conditions of confinement. While not dealing with COVID-era controversies, the foregoing case provides a framework for the Sixth Circuit's approach to habeas corpus that affirms, "where no set of conditions would be constitutionally sufficient, habeas is appropriate because the claim challenges the fact or extent [. . .] of the confinement." 125 In Adams v. Bradshaw, an Ohio death-row inmate challenged the state's method of execution, which involved lethal injection, by arguing that it was a violation of his Eighth Amendment rights. ${ }^{126}$ The plaintiff brought a claim for federal habeas corpus-based relief, which the court held was jurisdictionally cognizable. ${ }^{127}$

While lethal injection as a procedure for capital punishment is not facially analogous to conditions of confinement in a COVID context, both circumstances involve the consequence of death, albeit to differing extremities. While death is no guarantee when catching the novel coronavirus, the chance of fatality increases in individuals with specific risk factors and pre-existing medical proclivities. ${ }^{128}$ This common thread of fatality, however, raises the stakes in broadening the scope of doctrines on which the aggrieved may rely. This broadened scope should help high-risk prisoners in the Sixth Circuit, coupled with the authority of the forthcoming case.

The holding of this Sixth Circuit in Wilson v. Williams provides a small glimmer of hope for plaintiff inmates looking to gain COVID-based recourse on habeas claims. ${ }^{129}$ While the court found that the class-action plaintiffs would likely struggle to prove the subjective prong of Eighth Amendment deliberate indifference, habeas corpus jurisdiction would have, in fact, existed for the claims made by the plaintiff class had Congress not ratified the CARES Act, which has thus far worked as a lateral blockade to habeas jurisdiction in conditions of confinement claims (to be discussed further in this Note). ${ }^{130}$ The unusual facts of

125. Id. at $* 3$.

126. See Adams v. Bradshaw, 644 F.3d 481 ( $6^{\text {th }}$ Cir. 2011).

127. Id. at 483.

128. People with Certain Medical Conditions, Ctr. Disease Control \& Prevention, https://www.cdc.gov/coronavirus/2019-ncov/need-extra-precautions/people-with-medicalconditions.html [https://perma.cc/8PKU-B783] (last visited Nov. 7, 2020).

129. See Wilson v. Williams, 961 F.3d 829 (6th Cir. 2020).

130. See $i d$. The subjective prong details that plaintiffs are burdened with proving that prison officials failed to create safe conditions for prisoners in the midst of the COVID-19 pandemic. Id.; 
this case should not distract from the vehicle this holding provides for habeas admissibility in COVID-based cases. While the Court did establish that "even if the BOP's response has been inadequate, it has not disregarded a known risk or failed to take any steps to address the risk," the court still recognized the admissibility of an emergency habeas corpus petition on the strength of the Sixth Circuit's precedent in recognizing habeas in conditions of confinement claims. ${ }^{131}$

Had prison administration materially disregarded the threat of the virus and taken no steps to mitigate its dangers, the habeas petition may have worked in concert with the Eighth Amendment. This, in turn, would have produced a favorable outcome for the class of medically vulnerable plaintiff inmates. Plaintiff inmates, therefore, would be burdened with showing that conditions in prisons are so adverse to the extent that "no set of conditions would be constitutionally sufficient." 132 Pairing (a) a jurisdictional tolerance for habeas corpus in claims either regarding the location of confinement or involving facts so egregious as to call the constitutionality of the confinement into question with (b) a closer look by courts into the degree to which prison administration attempts to mitigate viral dangers would produce a more favorable landscape for plaintiff inmates. The Sixth Circuit is also not entirely alone in theoretical habeas-friendliness.

\section{Second Circuit Writ Recognition for Bail}

The split on the matter of habeas corpus admissibility in conditions of confinement claims does not pertain only to the Sixth and Seventh Circuits. Reflective of the high degree to which the virus has affected New York City and much of the surrounding Northeast, the Second Circuit is rich with recent case law involving plaintiff inmates' attempts to petition for bail through a number of legal theories - paramount of which involves habeas corpus petitions under $\S$ $2241 .^{133}$ While primarily dealing with petitions for release on bail and not necessarily home confinement, this recent influx of legal controversies on the matter of prisons and viral transmission in the Second Circuit reflects the Sixth Circuit's habeas-friendly approach. ${ }^{134}$

Since the beginning of the viral pandemic, the Second Circuit has not been afraid to hear petitions for habeas corpus based on dangers posed by communal living. ${ }^{135}$ In Martinez-Brooks v. Easter, decided by the U.S. District Court for the District of Connecticut, four inmates with COVID-19 risk factors filed a petition for writ of habeas corpus under $\S 2241$ against both the institution's Warden and

see, e.g., Miller v. Beard, No. 21-11, 2021 U.S. Dist. LEXIS 14246 (E.D. Ky. Jan. 26, 2021).

131. Id. at $* 843$.

132. Id. at $* 838$.

133. See, e.g., Martinez-Brooks v. Easter, No. 20-cv-00569, 2020 U.S. Dist. LEXIS 94038, at *4-5 (D. Conn. May 29, 2020); Basank v. Decker, No. 20 Civ. 2518, 2020 U.S. Dist. LEXIS 72178, at $* 27$ (S.D. N.Y. Apr. 23, 2020).

134. Id.

135. Id. 
the BOP Director. ${ }^{136}$ The inmates made a preliminary showing that officials at the institution made only limited use of the home confinement authority vested in them by Barr's memorandum. The inmates also showed that the failure of administration to "downsize immediately the incarcerated population and [. . .] to undertake aggressively the detection, prevention, and treatment measures that public health and medical experts have recommended, including effective social distancing" amount to deliberate indifference to a substantial risk of serious harm to inmates in violation of the Eighth Amendment. ${ }^{137}$ The plaintiff inmates brought other issues which raised factual disputes that precluded the court from granting relief outside of a temporary restraining order, but led to a quicker posting of bail. ${ }^{138}$ The court did, however, grant an order that requires the Warden to adopt a more efficient and clearly-focused process for evaluating the home confinement merits of inmates with risk factors. ${ }^{139}$ While dealing solely with a controversy surrounding bail, this case is apposite to the Sixth Circuit in that habeas-friendly adjudication can theoretically apply to COVID-era cases. Despite the respondents' argument that the court lacked jurisdiction over the habeas petition and that the plaintiffs failed to state a claim, the court explained that the respondents cited neither a Supreme Court nor a Second Circuit decision suggesting that release is unavailable to a $\S 2241$ petitioner asserting an Eighth Amendment claim. ${ }^{140}$ The court further explained that, per authority from Mapp v. Reno, the Second Circuit affords bail "in unusual cases, or when extraordinary or exceptional circumstances exist which make the grant of bail necessary to make the habeas remedy effective." ${ }^{141}$ Per the court's holding in Martinez-Brooks, it seems that plaintiff inmates in the Second Circuit are able to raise a habeas corpus $\S 2241$ claim for bail. This holds as long as they can prove that the insufficiency of prison administration in following proper protocol is an "extraordinary or exceptional circumstance," and that the habeas remedy is only effective when the grant of bail is made. ${ }^{142}$ Since the beginning of the viral pandemic, plaintiff inmates in the Second Circuit have relied on this authority in order to successfully petition for $\S 2241$ for the purpose of bail, and two primary cases emerged from the circuit that demonstrate the value of petitioning for habeas corpus in such a circumstance.

In Basank v. Decker, decided by the U.S. District Court for the Southern District of New York, the court found that the inmate petitioners established their entitlement to a preliminary injunction, and further found that detainees in the

136. Martinez-Brooks, 2020 U.S. Dist. LEXIS 94038, at*4-5. The inmates were held at the Danbury Federal Correctional Institution, the low-security prison in Connecticut that experienced the COVID-19 outbreak that triggered Attorney General Barr's memoranda to the BOP.

137. Id.

138. Id. at *3-4.

139. Id.

140. Id. at $* 4$.

141. Mapp v. Reno, 241 F.3d 221, 226 (2d Cir. 2001).

142. Martinez-Brooks, 2020 U.S. Dist. LEXIS 94038, at*9. 
facility at bar were not required to practice social distancing. ${ }^{143}$ The court further stated that, even if the petitioners had not met the requirements for a preliminary injunction, they would likely be released on bail pending final resolution of their habeas remedy. ${ }^{144}$ Staying consistent with the standard set in Mapp v. Reno, the court held that releasing the petitioners from confinement was necessary to "make the habeas remedy effective." 145 If the high-risk petitioners were to remain detained, "they would face a significant risk that they would contract COVID-19, the very outcome they seek to avoid." 146 Just as the Second Circuit has historically held that severe health issues have been the prototypical case of "extraordinary circumstances" that justify release under habeas corpus, the aforementioned circumstance involving the grave nature of allowing plaintiff inmates to live in adverse conditions also qualifies. ${ }^{147}$

Finally, in fellow Southern District of New York case Coronel v. Decker, the petitioners were detained by U.S. Immigration and Customs Enforcement ("ICE") and subsequently placed in a facility. ${ }^{148}$ This occurred despite each of the petitioners having medical conditions that put them at risk of catching the virus. ${ }^{149}$ In a departure from the prior two cases but providing a callback to claims made along the vein of the Eighth Amendment guarantee of livable conditions of confinement, the petitioners here brought a claim for deliberate indifference against the government for placing them in a high-risk arrangement despite their medical issues. ${ }^{150}$ The court reaffirmed the merit of the deliberate indifference claim, stating that the goal of the claim was "to ensure constitutionally adequate protection from COVID-19 in light of Petitioners' underlying health conditions." $"$ As was the case in Basank, the court found that "there is a likelihood that Petitioners are being subjected to unconstitutional conditions of confinement, and that the risks posed by COVID-19 are imminent." ${ }^{152}$ The court therefore found that these risks made release on bail necessary to "make the habeas remedy effective." ${ }^{153}$ On its face, this looks great for plaintiff inmates not necessarily covered by the CARES Act; when paired with an Eighth Amendment conditions of confinement claim to effectuate release on bail, the habeas writ

143. Basank v. Decker, No. 20 Civ. 2518, 2020 U.S. Dist. LEXIS 72178, at *27 (S.D. N.Y. Apr. 23, 2020). Those detainees who exhibited COVID-19 symptoms, the court found, often waited to receive medical attention, were not separated from cell mates, and may have been returned to the general population anyway.

144. Id.

145. Id. (quoting Mapp, 241 F.3d at 226).

146. $I d$. at $* 35$.

147. Id. at $* 34$.

148. Coronel v. Decker, 449 F. Supp. 3d 274, 289 (S.D. N.Y. 2020).

149. Id.

150. Id.

151. Id.

152. Id.

153. Id. 
seems to do its job. ${ }^{154}$ However, while habeas jurisdiction is cognizable for bail in the Second Circuit, the question remains whether the writ in practice effectuates home confinement for those serving sentences in federal prisons.

\section{HAS HABEAS CORPUS ACTUALLY MOVED A PRISONER'S SENTENCE TO HOME CONFINEMENT?}

Thus far, no court in any jurisdiction, including the Sixth Circuit, has recognized habeas corpus as a proper means of attaining home confinement in an Eighth Amendment COVID-based claim. In such cases, courts have laterally held that the standard of release to home confinement, as prescribed by former Attorney General Barr, cannot be sidestepped by a $\S 2241$ claim. ${ }^{155}$ Despite roughly 20,000 federal inmates having been granted home confinement since March 2020, the fact remains that over $46 \%$ of federal inmates have contracted the novel coronavirus, and at least 240 federal inmates and even a few BOP staff members have died from contracting the virus. ${ }^{156}$

Despite being from the Sixth Circuit, the court in the January 2021 case Miller v. Beard out of the Eastern District of Kentucky, Northern Division denied the plaintiff's petition for the writ of habeas corpus based on pandemic-related dangers. ${ }^{157}$ Miller is far from the only instance of petition denial in the Sixth Circuit or otherwise, as no court has allowed for the writ of habeas corpus to provide relief for plaintiff inmates during the pandemic. In this case, Plaintiff Miller - an inmate at F.C.I. Ashland (Kentucky) - asserted that prison officials are "not doing enough to combat the spread of COVID-19 at the prison," and have not "adequately utilized the authority conferred upon them by the [CARES] Act to transfer inmates to home confinement or to grant compassionate release." ${ }^{158}$ Miller further requested that the court order BOP officials to release more inmates at F.C.I. Ashland through the avenues allowed by the CARES Act, and to be excused from the requirement of exhausting administrative remedies prior to filing suit under a $\S 2241$ claim. ${ }^{159}$

Under Fazzini v. Ne. Ohio Correctional Center, a prisoner must exhaust their administrative remedies with the BOP before seeking habeas relief under $\S$ $2241 .{ }^{160}$ Therefore, aggrieved prisoners, like Miller, must file an inmate grievance regarding their concerns and further pursue an appeal process under the BOP's Inmate Grievance Program. ${ }^{161}$ Miller sought exclusion from the exhaustion

154. See Basank v. Decker, No. 20 Civ. 2518, 2020 U.S. Dist. LEXIS 72178 (S.D. N.Y. Apr. 23, 2020); see also Coronel v. Decker, 449 F. Supp. 3d 274 (S.D. N.Y. 2020).

155. See, e.g., Miller v. Beard, No. 21-11, 2021 U.S. Dist. LEXIS 14246 (E.D. Ky. Jan. 26, 2021).

156. COVID-19 Coronavirus, supra note 9 .

157. See Miller, 2021 U.S. Dist. LEXIS 14246.

158. Id. at *3.

159. Id.

160. Fazzini v. Ne. Ohio Correctional Ctr., 473 F.3d 229, 231 (6th Cir. 2006).

161. See id. 
requirement "because of the dangerous conditions at F.C.I. Ashland."162 This is to say that Miller thought it deleterious to his health and that of fellow inmates to wait through an administrative process when viral threats perpetuated in their living quarters. ${ }^{163}$

The court denied Miller's petition because, while the CARES Act authorizes the BOP to consider placing an inmate in home confinement, "it does not require it to do so." 164 The BOP has absolute power in making this determination; while the American Procedures Act usually provides an avenue for judicial review of these decisions, 28 U.S.C. $\S 3625$ exempts the BOP's placement decisions from this review. ${ }^{165}$ The court further stated that "a prisoner may not invoke the Court's habeas corpus jurisdiction in an effort to sidestep the limitations and requirements of the CARES Act."166

Even if Miller had (a) formalized an Eight Amendment argument surrounding his claim that prison officials had not "done enough" to contain the virus; (b) asserted that prison officials exhibited "deliberate indifference" in inadequately protecting the facility's prisoner population from viral threats; and (c) used a petition for the writ of habeas corpus to effectuate home release, the inability of a prisoner to invoke habeas corpus jurisdiction to sidestep the requirements of the CARES Act would have precluded Miller from relief anyway. This is but one example of habeas not working the way that the habeas-friendly side of the circuit split made it seem like it would. A fellow district court case in the Sixth Circuit, Woods v. Beard, concluded in the denial of the writ of habeas corpus to another inmate a month prior to the Miller case on identical grounds. ${ }^{167}$ Even the court in the aforementioned Wilson $v$. Williams case found that habeas jurisdiction was at the very least - cognizable, despite the petitioners' likely difficulty in proving "deliberate indifference" under the Eighth Amendment. There, the court held that "a district court reviewing a claim under $\S 2241$ does not have authority to circumvent the established procedures governing the various forms of release enacted by Congress." 168 The primary "form[] of release enacted by Congress" that provides the roadblock to habeas corpus relief for aggrieved plaintiff inmates is manifest in former Attorney General Barr's directions to the BOP. The holding of Wilson makes it clear - a court will not invoke habeas corpus jurisdiction during the COVID-19 pandemic so long as no legal challenge to the authority of established governmental procedures of release exists. ${ }^{169}$

The judicial inadmissibility of motions for the writ of habeas corpus on conditions of confinement claims during the COVID-19 pandemic is not confined

162. Miller, 2021 U.S. Dist. LEXIS 14246, at*4.

163. See id.

164. Id.

165. Id.

166. Id. (quoting Price v. Quintana, No. 20-246, 2020 U.S. Dist. LEXIS 107395 (E.D. Ky. June 19, 2020)).

167. See Woods v. Beard, No. 20-151, 2021 U.S. Dist. LEXIS 7440 (E.D. Ky. Jan. 14, 2021).

168. Wilson v. Williams, 961 F.3d 829, 839 (6th Cir. 2020).

169. See id. 
to just the federal circuits analyzed in this Note. To the detriment of plaintiff inmates, courts in the Eighth and Eleventh Circuits continue to rule unfavorably toward those who assert conditions of confinement claims in a habeas petition. For example, the ACLU of Minnesota filed a lawsuit against the Federal Correctional Institution of Waseca, Minnesota, in December 2020. ${ }^{170}$ The Minnesota ACLU alleged that the prison "failed to take sufficient steps to prevent the spread of the coronavirus and did not provide adequate health care as the virus swept through the facility." prison's inmates had contracted the virus. ${ }^{172}$ In pursuit of release into home confinement for the fourteen inmates, the Minnesota ACLU petitioned for the writ of habeas corpus. ${ }^{173}$ While the U.S. District Court for the District of Minnesota precluded plaintiffs from relief, just as Miller was unsuccessful in his claims against F.C.I. Ashland, the reasoning of the appellate and magistrate judges was more akin to the Seventh Circuit holdings. ${ }^{174}$ As such, this March 2021 decision establishes that the Eighth Circuit falls on the Seventh Circuit's side of the split in providing no relief on the plaintiffs' conditions of confinement grounds. ${ }^{175}$ The judges affirmed that "a writ of habeas corpus [cannot] be used when inmates are claiming they are incarcerated in unsafe conditions [. . .]."176 Independent of any mention of the CARES Act or its inability to be "sidestepped" by habeas, the judges here established that pandemic-related dangers, even in a facility that saw seven out of every ten inmates contract the virus, are not enough to supersede the circuit's precedent that plaintiff-inmates cannot petition for habeas on conditions of confinement grounds. ${ }^{177}$ Indeed, the Court here affirmed that " $[\mathrm{t}]$ he Eighth Circuit holds that a prisoner may not assert a constitutional claim relating 'to the conditions of [their] confinement' in a 'habeas petition." The court further highlighted that a writ of habeas corpus is not the proper remedy in the Eighth Circuit " [i]f the prisoner is not challenging the validity of [their] conviction or the length of [their] detention [. . .]." ${ }^{179}$ Under a similar fact

170. Kristine Goodrich, ACLU Lawsuit Against Waseca Prison Dismissed, FreE Press (Mar. 23, 2021), https://www.mankatofreepress.com/news/local_news/aclu-lawsuit-against-wasecaprison-dismissed/article_6e92290e-8c21-11eb-a691-f75dbd38dd34.html [https://perma.cc/JJ8RDVHF].

171. Id.

172. $I d$.

173. Id.

174. Id.; see Miller v. Beard, No. 21-11, 2021 U.S. Dist. LEXIS 14246 (E.D. Ky. Jan. 26, 2021).

175. See Goodrich, supra note 170; see also Savage v. Warden of FCI Pekin, No. 20-cv-1181, 2020 WL 4060768, at *2 (C.D. Ill. July 20, 2020) (citing Waletzki v. Keohane, 13 F.3d 1079, 1080 (7th Cir. 1994)).

176. Goodrich, supra note 170.

177. See id.; see also, e.g., Miller, 2021 U.S. Dist. LEXIS 14246.

178. Malcom v. Starr, No. 20-2503, 2021 U.S. Dist. LEXIS 45387, at *6-7 (D. Minn. Mar. 11, 2021) (quoting Spencer v. Haynes, 774 F.3d 467, 470 (8th Cir. 2014)).

179. Id. at*7. (quoting Kruger v. Erickson, 77 F.3d 1071, 1073 (8th Cir. 1996)). 
pattern from the Southern District of Alabama in Royster v. Oliver, the Eleventh Circuit has followed suit in holding that habeas brings no cognizable means of relief in pandemic-related conditions of confinement cases. ${ }^{180}$ There, the court firmly held that "the Eleventh Circuit has 'concluded that a petition for a writ of habeas corpus is not the appropriate mechanism for contesting a prisoner's conditions of confinement." ${ }^{181}$ Narrowing the scope to COVID-based claims, the court concluded that " [a]ccordingly, courts in this circuit [. . .] have concluded that they lack habeas jurisdiction over claims related to the risk posed by COVID19." $" 182$

In the context of the split between the Sixth and Seventh Circuits, this conclusion regarding the lateral inadmissibility of habeas corpus in COVID-based claims is unexpected. Prior to the pandemic, the Sixth Circuit championed the admittance of habeas corpus jurisdiction when conditions of the location of confinement proved adverse to the point of calling the legality of the detention into question. ${ }^{183}$ Now, plaintiff inmates who find themselves not covered by the CARES Act are without remedy due to the blockade of former Attorney General Barr's direction to the BOP and subsequent criteria for home release. "Deliberate indifference" on the part of prison staff in their protection of prisoners from viral threats is hard for plaintiff inmates to prove. ${ }^{184}$ This "deliberate indifference" standard is tough in that it requires proof of reckless disregard for a known threat. ${ }^{185}$ Worse for these plaintiff inmates, habeas corpus cannot crack the authority of a congressionally-ratified plan for release like the CARES Act. ${ }^{186}$ The COVID-19 pandemic compelled Congress to enact and the former Attorney General to guide the enforcement of a plan of action. ${ }^{187}$ The plan's implementation dulled the strength of habeas corpus as a result. ${ }^{188}$

\section{WHERE DO We GO FROM HERE?}

While courts have not yet granted petitions for the writ of habeas corpus as a remedy for inmates not covered by the CARES Act, legal practitioners can learn from courts' treatment of habeas claims and from the intersection between the pandemic and prison law, in general.

180. Royster v. Oliver, No. 21-00102-CG-B, 2021 U.S. Dist. LEXIS 49696, at *9 (S.D. Ala. Mar. 15, 2021).

181. Id. (quoting A.S.M. v. Donahue, No. 20-CV-62, 2020 U.S. Dist. LEXIS 65226, at*3-4 (M.D. Ga. Apr. 10, 2020)).

182. Id. (quoting S.S. v. Stewart Det. Ctr., No. 20-CV-59-CDL, 2020 U.S. Dist. LEXIS 243494, at *5 (M.D. Ga. Oct. 15, 2020)).

183. See, e.g., Adams v. Bradshaw, 644 F.3d 481 (6th Cir. 2011).

184. See Farmer v. Brennan, 511 U.S. 825 (1994).

185. See id.

186. See Miller v. Beard, No. 21-11, 2021 U.S. Dist. LEXIS 14246, at *4 (E.D. Ky. Jan. 26, 2021).

187. Memorandum from Att'y Gen. William P. Barr, supra note 20.

188. See generally Miller, 2021 U.S. Dist. LEXIS 14246, at*4. 
A question arising from the pandemic is how courts treat the "deliberate indifference" standard of Eighth Amendment conditions of confinement claims. ${ }^{189}$ While no federal prisoner has successfully paired a habeas corpus petition with proof of "deliberate indifference" by prison staff to the threats of the virus, the amount of prisoners who have complained about prisons doing an inadequate job of protecting against the virus is voluminous. ${ }^{190}$ The context of the pandemic compels courts to draw a line in the sand; a global viral threat that results in nearly half of the federal prison population contracting a virus should per se fit the definition of "deliberate indifference" in spaces where protocol is not followed. It follows, too, that making prison staff strictly liable for the positive tests of their inmates may not give sufficient deference to the many institutions that follow protocol as best they can and still report positive cases. Secondarily, had former Attorney General Barr's direction to the BOP director and subsequent criteria for release not included the relatively untested PATTERN electronic algorithm system, it is likely that fewer prisoners will be or would have been precluded from attaining home release. ${ }^{191}$ The advent of COVID-19, too, should allow the legal community the chance to further discuss the problems associated with prison overcrowding and the disparate impact of systems of detention and release on BIPOC individuals.

The greater conversation regarding inmate advocacy in a viral pandemic has already begun. To combat this disparate impact of viral transmissibility on incarceration settings, Health Equity Task Force member Homer Venters proposes a system of independent audits. ${ }^{192}$ This auditing, according to Venters, "involves creating an official role for the CDC [. . .] in measuring how well carceral settings are doing in these complex [mitigation] tasks, not leaving the assessment of adequacy up to [prisons] to report." 193 Further, Venters urges systems of auditing to "include measuring whether and how facilities are implementing CDC guidelines and assessing whether deaths from COVID-19 related illnesses reflect systemic difficulties in facility responses." 194

Even after vaccination mitigates the threat of the novel coronavirus to the degree that Americans can resume their lives as normal, legal issues surrounding a prisoner's ability to appeal their sentence on the grounds of the adverse nature of its setting will still be relevant. This is especially true in a post-COVID-19 society that will likely be more conscious of disease control and sensitive to the conditions of those who may pose a greater risk of bodily ailment or death when exposed to a transmittable virus. Although the Eighth Amendment theoretically stands to protect those subjected to the American prison system, individuals put into federally funded and administered custody should not have to be subjected to conditions deleterious to their health and ability to rehabilitate, appeal, or

189. See Farmer, 511 U.S. at 825.

190. See Miller, 2021 U.S. Dist. LEXIS 14246, at*4.

191. Memorandum from Att'y Gen. William P. Barr, supra note 20; Hager, supra note 84.

192. Harrison, supra note 18.

193. Id.

194. Id. 
otherwise operate as a member of society. Sans COVID-19, the Sixth Circuit recognizes the strength of habeas corpus to supersede the barriers constructed by legal precedent against plaintiff inmates seeking release when the adverse conditions of confinement go beyond that which should be tolerable under American jurisprudence. ${ }^{195}$ The same can be said for the Second Circuit, which has gone further in allowing the pandemic to effectively modify what qualifies as an "extraordinary circumstance" 196 that triggers habeas in bail controversies. All jurisdictions should follow suit by recognizing the threats of the COVID-19 virus, its morbid dangers to elderly and at-risk individuals, and the speed of its transmissibility as part of a larger "extraordinary circumstance."197

In hypothesizing the post-pandemic state of improving health in detention settings, Homer Venters urges that society " [ . . . need[s] to be honest about the health risks of incarceration. Going to jail, prison, and immigration detention brings health risks to people, and the thousands of COVID-19 deaths among detained people provide a devastating example of this truth." ${ }^{198}$ While Venters hopes to "leverage the involvement of public health agencies in COVID-19 behind bars" to create substantive change, responsibility falls, too, on the judiciary in providing equitable outcomes for aggrieved plaintiff inmates not covered by the CARES Act. ${ }^{199}$ The strength of the federal legislature and the former executive administration in ratifying the CARES Act provided a blockade that the judiciary has failed to overcome. ${ }^{200}$ During the COVID-19 pandemic, not one plaintiff inmate has effectuated an Eighth Amendment conditions of confinement claim with a petition for the writ of habeas corpus. ${ }^{201}$ What courts ignore, or at the very least what the CARES Act precludes courts from recognizing, is that both the Second and Sixth Circuits - different from the Seventh, Eighth, and Eleventh Circuits - recognize petitions for the writ of habeas corpus in effectuating a conditions of confinement claim. ${ }^{202}$ In the Sixth Circuit, the holding of Adams v. Bradshaw and the court's recognition of habeas in

195. See e.g., Adams v. Bradshaw, 644 F.3d 481 (6th Cir. 2011).

196. Mapp v. Reno, 241 F.3d 221, 226 (2d Cir. 2001). The Second Circuit affords bail "in unusual cases, or when extraordinary or exceptional circumstances exist which make the grant of bail necessary to make the habeas remedy effective."

197. Id.

198. Harrison, supra note 18.

199. Id.

200. See Price v. Quintana, No. 20-246, 2020 U.S. Dist. LEXIS 107395 (E.D. Ky. June 19, 2020).

201. See, e.g., Miller v. Beard, No. 21-11, 2021 U.S. Dist. LEXIS 14246, at*4 (E.D. Ky. Jan. 26, 2021).

202. See Savage v. Warden of FCI Pekin, No. 20-cv-1181, 2020 WL 4060768 (C.D. Ill. July 20, 2020) (holding that the Sixth Circuit has recognized that habeas jurisdiction is able to cover claims involving conditions of confinement that rise to an extremely adverse level); see also Mapp v. Reno, 241 F.3d 221, 226 (2d Cir. 2001) (explaining that the Second Circuit affords bail "in unusual cases, or when extraordinary or exceptional circumstances exist which make the grant of bail necessary to make the habeas remedy effective"). 
Wilson v. Williams stand analogous to the efforts of those seeking habeas petitions since the beginning of the pandemic. ${ }^{203}$ In the Second, while plaintiffs have found success during the pandemic in petitioning for the writ in obtaining bail instead of relocating their sentences, the fact that cases Martinez-Brooks v. Easter, Basank v. Decker, and Coronel v. Decker produced holdings favorable to plaintiffs raises a legitimate question as to their authority in conditions of confinement claims from incarcerated individuals. ${ }^{204}$

\section{CONCLUSION}

Focusing on the circuit split which provided the occasion for this inquiry, a more liberal interpretation of habeas corpus admissibility based in Eighth Amendment conditions of confinement claims - where the conditions would have to be proven as challenging the fact of confinement - is the more equitable path during the COVID-19 crisis. The worldwide viral pandemic allows for a context through which legal practitioners can analyze the strength of habeas corpus. Until authorities publish further information on the matter, legal advocates for habeas corpus jurisdiction cannot purport to say that any of the 200-plus lives lost in federal prisons could have been avoided with the admittance of habeas corpus jurisdiction. ${ }^{205}$ We fail to know how many of these deaths involved individuals with cognizable risk factors. A discussion regarding the mere potential for these individuals to have obtained representation in the first place beyond the scope of

203. See Adams v. Bradshaw, 644 F.3d 481, 483 (6th Cir. 2011) (holding an Ohio death-row inmate challenging the state's method of execution, which involved lethal injection, by arguing that it was a violation of his Eighth Amendment rights could successfully petition for the writ of habeas corpus); see also Wilson v. Williams, 961 F.3d 829 (6th Cir. 2020) (holding habeas corpus jurisdiction would have, in fact, existed for the claims made by the plaintiff class had Congress not ratified the CARES Act).

204. See Martinez-Brooks v. Easter, No. 20-cv-00569, 2020 U.S. Dist. LEXIS 94038, at*4-5 (D. Conn. May 29, 2020) (holding a petition for the writ of habeas corpus for bail was cognizable where the inmates made a preliminary showing that officials at the institution made only limited use of the home confinement authority vested in them by Barr's memorandum, and that the failure of administration to "downsize immediately the incarcerated population and [. . .] to undertake aggressively the detection, prevention, and treatment measures that public health and medical experts have recommended, including effective social distancing" amount to deliberate indifference to a substantial risk of serious harm to inmates in violation of the Eighth Amendment); Basank v. Decker, No. 20 Civ. 2518, 2020 U.S. Dist. LEXIS 72178, at*35 (S.D. N.Y. Apr. 23, 2020) (quoting Mapp, 241 F.3d at 226) (holding releasing the petitioners from confinement in this case was necessary to "make the habeas remedy effective" in the circumstance where, if the high-risk petitioners were to remain detained, "they would face a significant risk that they would contract COVID-19, the very outcome they seek to avoid"); Coronel v. Decker, 449 F. Supp. 3d 274 (finding a petition for habeas corpus cognizable where "there is a likelihood that Petitioners are being subjected to unconstitutional conditions of confinement, and that the risks posed by COVID19 are imminent").

205. COVID-19 Coronavirus, supra note 9. 
this Note. Further discussion regarding the threat of prison overcrowding and, notably, the Prison Litigation Reform Act ("PLRA") is also better analyzed in a Note that is not predicated on a habeas theme. ${ }^{206}$ However, the pandemic should serve as an example for legal practitioners; perhaps it is important to advocate for the ability of our most fundamental American legal doctrines to gain a level of usability in modern contexts.

The viral pandemic will end, but that end has not yet occurred. An ancient legal doctrine like habeas corpus should be construed as to provide relief where the legislature cannot. If greater health and prison law is to reflect pure equity, the legal community must take and recognize the power that their own jurisdictions may give to the writ of habeas corpus.

206. See 18 U.S.C. $§ 3626($ a)(3). The PLRA requires a special three-judge panel to be requested and convened to decide whether prisoners should be released from prison based on illegal conditions of confinement caused by overcrowding, but the PLRA also requires there be evidence of a prior court order with less intrusive relief that failed to remedy the deprivation of the federal right sought to be remedied after the prison defendants had a reasonable amount of time to comply. Malcom v. Starr, No. 20-2503, 2021 U.S. Dist. LEXIS 45387, at*5 (D. Minn. Mar. 11, 2021). Although the Act is a vehicle for plaintiff inmates bringing Eighth Amendment conditions of confinement claims, because this process is wholly different from and does not pertain to a petition for the writ of habeas corpus, an analysis of the PLRA and COVID-era controversies does not appear in this Note. 